\section{Kastamonu Eğitim Dergisi Kastamonu Education Journal}

Mayıs 2019 Cilt:27 Sayı:3

kefdergi.kastamonu.edu.tr
Başvuru Tarihi/Received: 19.02.2018

Kabul Tarihi/Accepted: 11.06 .2018

DOI: $10.24106 /$ kefdergi.2722

\title{
Okul Öncesi Dönemde Çocukların Oyun Davranışları Düzeylerinin Çeşitli Değişkenler Açısından İncelenmesi
}

\section{Analyzing Pre-school Children's Play Behaviors According to a Variety of Variables}

\section{Öz}

\author{
Gürol YOKUŞ ${ }^{1}$, Gamze YAVUZ KONOKMAN²
}

Okul öncesi dönem çocukların sosyo-duygusal becerilerinin gelişimi açısından oldukça kritik bir dönemdir. Okul öncesi dönem çocukların saygı, sosyal paylaşım, iş bölümü, bireysel hak ve sorumluluklar, sosyal çevre gibi pek çok yeterlilikleri kazandığı ve bireyi yetişkin hayatına hazırlayan önemli dönemlerden biridir. Bu çalışmada okul öncesi dönemi çocuklarının sessiz oyun, yalnız-pasif oyun, yalnız-aktif oyun, sosyal oyun ve itiş-kakış oyun davranışları belirlenmiş ve çeşitli değişkenler bağlamında incelenmiştir. Araştırma yöntemi olarak nicel yöntemlerden betimsel yöntem kullanılmıştır. Çalışma grubunu Mersin Illinde seçkisiz olarak belirlenen özel ve devlet okul öncesi eğitim kurumlarında öğrenim gören 60-72 aylık 200 çocuk oluşturmaktadır. Araştırmacılar kurumlarda görev yapan öğretmenlerle görüşerek, öğretmenlerden oyun davranışı ölçeğini her çocuk için gözlemlerine dayanarak doldurmalarını istemiştir. Analiz sonucunda, okul öncesi dönemi çocuklarının oyun davranışları olarak en yüksek puanı sosyal oyun davranışlarından aldıkları, daha sonra orta düzeyde yalnız-aktif oyun ve sessiz oyun davranışlarına sahip oldukları, en düşük puanları ise itiş-kakış oyun ve yalnız-pasif oyun alt ölçeklerinden aldıkları görülmüştür. Çocukların oyun davranışlarının kardeş değişkenine göre farkılışıp farklılaşmadığına bakıldığında, kardeşi olmayan çocukların bir ya da iki kardeşi olanlara kıyasla daha düşük itiş-kakış oyun oynadıkları görülmüştür. Bu çalışma kapsamında, çocukların oyun davranışlarının eğitim aldıkları kurum türüne göre farklılaşıp farklılaşmadığına bakıldığında ise özel kurumda öğrenim gören okul öncesi dönemi çocuklarının yalnız-aktif oyun davranışlarının devlet kurumlarında öğrenim görenlere kıyasla daha yüksek olduğu görülmüştür.

\section{Anahtar Kelimeler: okul öncesi oyun davranışları, sosyal oyun, sosyo-duygusal gelişim}

\section{Abstract}

Pre-school stage is a critical period for socio-emotional development of children. Children gain a variety of competences like respect, social share, labor division, individual rights and responsibilities, social environment during pre-school; therefore, it's a preparation process children go through for adult life. This study aims to identify the current situation of pre-school children's play behaviors (silent play, solitary-passive play, solitary-active play, social play and reticent play behaviors). Also, it is identified in this study whether pre-school children's play behaviors differ depending on various variables. Descriptive method -one of the quantitative research methods- has been used as a research method. Study sample includes 200 children selected randomly whose ages range from 60 months to 72 months and study in private and public pre-schools in Mersin. Teachers have been asked to observe each child and then fill "play behaviors scale". As a result of analysis, it is seen that pre-school children obtain highest scores in subscales of social play, then moderate scores in subscales of solitary-active play and silent play, then the lowest scores in reticent play and solitary-passive play. In terms of sibling variable, it comes out that children with no sibling show higher degree of reticent play behaviors compared with children with one or two siblings. Within context of this research, it is found out that pre-school children who go to a private school show higher degree of solitary-active play behaviors compared with children who go to a public school

Keywords: pre-school play behaviors, social play, socio-emotional development

1. Sinop Üniversitesi, Eğitim Programları ve Öğretim A.B.D., Sinop, Türkiye; https://orcid.org/0000-0002-4849-5829

2. Bartın Üniversitesi, Eğitim Programları ve Öğretim A.B.D., Bartın, Türkiye; https://orcid.org/0000-0003-2272-1549

Atıf / Citation: Yokuş, G., ve Yavuz Konokman, G. (2019). Okul öncesi dönemde çocukların oyun davranışları düzeylerinin çeşitli değişkenler açısından incelenmesi. Kastamonu Education Journal, 27(3), 1141-1148. doi:10.24106/kefdergi.2722 


\section{Extended Summary}

Pre-school stage is a critical period for socio-emotional development of children. Children gain a variety of competences like respect, social share, labor division, individual rights and responsibilities, social environment during pre-school; therefore, children go through a preparation process for adult life.

Purpose This study aims to identify the current situation of pre-school children's play behaviors, social competence and school adjustment behaviors. Also, this study aims to identify whether pre-school children's play behaviors, social competence and school adjustment behaviors differ depending on a variety of variables. These variables include the type of institution children go to and the number of siblings they have.

Method Descriptive method has been preferred in this study as research method which is done for identifying pre-school children's play behaviors and to identify whether pre-school children's play behaviors differ depending on various variables.

Sample Study Sample study includes 200 children selected randomly whose ages range from 60 months to 72 months and study in private and public pre-schools in Mersin. The demographic features of sample include: 117 females (\%58.5); 83 males (\%41.5); 120 participants (\%60) go to private schools, 80 participants (\%40) go to public schools. 80 participants (\%40) have no siblings, 102 participants (\%51) have one sibling, and 18 participants (\%9) have two siblings.

Data Collection Tool In this study, Pre-school Play Behaviors Scale was used which were developed by Coplan and Rubin (1998) in order to identify children's behaviors which they show while playing. Teachers were asked to observe each child and then fill "play behaviors scale".

Analysis of Data Descriptive statistics were used for explaining pre-school children's play behaviors. Also, test of differences were made in order to analyze whether the type of institution and the number of sibling lead to a statistically significant different on children's play behaviors.

Findings It is found that pre-school children obtain high scores in subscales of social play, solitary-active play, silent play, reticent play and solitary-passive play. Based on this high arithmetic mean of subscales, it is possible to claim that children often show paly behaviors. In terms of institution type, it is seen that there is a significant difference in solitary-active play behaviors of children depending on type of institution they go to (t198=3.172, $p<.05)$. Children who go to private pre-schools show higher amount of solitary-active play behaviors when compared with children who go to public schools. Also, in terms of the number of siblings variable, it is seen that there is a significant difference in reticent play behaviors of children $F(2,197)=3.128 ; P<.05$. According to $L S D$ test result which is done for identifying the source of this difference, it is found out that children with no sibling show lower amount of reticent play behaviors $(=7.00)$ when compared to children with one sibling $(=7.31)$ or two siblings $(=8.75)$. With regards to this finding, it is possible to claim that the number of sibling affects pre-school children's reticent play behaviors.

To conclude, as a result of this research, it is found out that pre-school children obtain highest scores in subscales of social play and solitary-active play, then in subscales of silent play and reticent play. They had the lowest scores in solitary-passive plays. In terms of sibling variable, it comes out that children with no sibling show higher amount of reticent play behaviors compared with children with one or two siblings. Within context of this research, it is found out that pre-school children who go to a private school show higher amount of solitary-active play behaviors compared with children who go to a public school. Likewise, Taylı (2007) in his research found out that children with no sibling show more solitary play behaviors when compared to children with sibling. According to him, solitary play is the type of play in which there exist highest number of disputes, conflicts and view differences among children. It is also found out that solitary-passive play is associated with exclusion by friends, inter-personal relation problems and internalization of problem; solitary-active play is associated with less static, offensiveness and externalization of problem. In study of Ogleman and Sarıkaya (2014); it was found out that as there is an increase in solitary-passive and solitary-active play behaviors; there exists also an increase in children's positive social behaviors; however, an increase in reticent play behaviors mean an increase in hyperactivity, anxiousness and exposure to peer violence. With respect to the type of school, Altay and Güre (2012) made a research and found out that it led to a difference in subscales of social competence which include negative relations with peers and participation. Children who go to private pre-schools show higher degree of offensive and non-participative behaviors when compared with children who go to public pre-schools. 


\section{Giriş}

Günümüz toplumlarında bireylerin ihtiyaçlarının çeşitlenmesi, bu ihtiyaçların sürekli artışı ve bireyin bu ihtiyaçları etkin bir şekilde karşılayarak kişisel gelişimini sağlıklı bir şekilde sürdürmesinde okul öncesi eğitimin katkısı oldukça büyüktür. Okul öncesi eğitim 21. yüzyıl toplumunda ihtiyaç duyulan insan tipini yetiştirmek için önemli bir gereklilik olarak karşımıza çıkmaktadır. Okul öncesi eğitimin bireylerin öğrenme yeterliliklerini desteklediği; bireyler üzerinde sosyal, zihinsel ve psikolojik olarak olumlu etkiler bıraktı̆̆ vurgulanmaktadır. Bununla ilgili olarak, Bierman ve Motamedi (2015) okul öncesi dönemin sosyo-duygusal becerilerin gelişimi açısından kritik bir dönem olduğunu, 3-6 yaş arasında pek çok çocuğun sorumluluk, kurallara uyma, mantı yürütme, öz-kontrol, duygularının farkına varma ve düzenleme, sosyallik gibi çeşitli beceriler açısından önemli ilerleme kaydettiğini belirtmiştir. Alan yazında da okul öncesi eğitimin bireyin yaşamı üzerindeki etkileri hakkında yapılmış çalışmaların sayısı gün geçtikçe artmaktadır. Okul öncesi eğitim kurumları saygı, sosyal paylaşım, iş bölümü, bireysel hak ve sorumlulukların öğrenilmesi ve sosyal çevre oluşturma açısından bireyi yetişkin hayatına hazırlayan önemli kurumlardan biridir. Günalp (2007)'e göre, okul öncesi eğitimde çocuk cinsel kimliğini kazanarak benlik kavramını geliştirmekte, kendini ifade edebildiği için özdenetimini geliştirmekte ve kendine güvenli bağımsız bir kişilik kazanmaktadır. Ayrıca bu kurumlar çevre uyarıcıları ile çocuğun akıl yürütme yeteneğine, yaratıcılığına ve hayal gücünün gelişimine katkı sağlamaktadırlar. Okulöncesi eğitim kapsamında üzerinde en çok durulan konulardan birisi çocukların bu dönemde en çok ilgi duydukları konu olan oyundur. Çocukların oyunlarda akranlarına karşı gösterdikleri davranışlar, yaptığı sosyal paylaşımlar, yaşadığı problemlerde verdiği tepkiler ve problem çözme biçimleri çocuğun bilişsel ve duyuşsal dünyası hakkında önemli veri sağlamaktadır. Bununla ilgili olarak Kaytez ve Durualp (2014) çocuğun yaşam için gerekli davranışları, bilgi ve becerileri oyun içinde kendiliğinden öğrendiğini; bir çocuğun bedensel ve ruhsal yönden sağlıklı gelişimi ve eğitimi için oyunun, beslenme ve uyku kadar önemli bir ihtiyaç olduğunu vurgulamıştır. Çocuklar için oyunlar gelişigüzel eylemler değil, oldukça ciddiye aldıkları bir uğraştr (Firdevs, 2015); dolayısıyla çocukların oyun davranışların incelenmesi çocukların duyuşsal ve davranışsal problemlerinin ortaya çıkartılması ve birtakım çözümler ortaya koyma amacıyla sıklıkla başvurulan bir yöntemdir (Openheim ve diğerlerleri, 1997; Coplan ve Rubin, 1998; Cohen ve Mendez, 2009; Aslan, 2013; Kaytez ve Durualp, 2014). Çocuğun grup içine katılma, sağlıklı ilişkiler kurma, kültür değerlerini öğrenme, kendini tanıma ve sosyalleşmesinin okulöncesi yaşlarda oyun yoluyla gerçekleştiği; bağımsızlaşma, sosyal rollerin edinimi, çocuğun ana-babadan bağımsızlaşması, bireyin potansiyelini ortaya çıkarma, okula uyumu gibi bilişsel, sosyal ve fiziksel alanlardaki becerilerin çocuğun oyun davranışları ile yakından ilgili olduğu düşünülmektedir. Okul öncesi dönemde çocuğun gelişimini etkileyen pek çok değişken bulunmaktadır. Bu değişkenlerin en önemlilerden biri de oyundur. Bu çalışma kapsamında okul öncesi dönemde oyunun ne olduğuna dair çeşitli çalışmalar incelenmiş, oyun değişkeni ile sosyal yeterlik ve okula uyum değişkeni arasındaki ilişki ortaya konmaya çalışılmıştır.

\section{Oyun Tanımlamaları ve Oyunun Kavramsallaştırılması}

Oyun kavramının ne anlama geldiği, içeriğinin ne olduğu, çocukları oyun başlatma davranışlarına iten sebepler, çocukların oyun oynama amaçları ve çocuğun gelişimi üzerindeki etkisinin araştııımasında öncelikle oyun kavramının tanımlanması önemlidir. Alan yazına bakıldığında oyuna ve oyunun barındırdığı eğitsel değerlere karşı hep giderek artan bir ilgi olduğu görülmektedir. Çeşitli araştırmacılar tarafindan sosyal yeterlik, okul başarısı, öfke davranışları, başkalarının düşüncelerini anlama ve benzeri birçok konuda oyunun oynadığı rol araştırılmıştır (Strayer ve diğerleri, 2004; Zimmerman, 2003; Youngblade ve Dunn, 1995). Ginott (1994) oyunun çocuklara fikirlerini ve duygularını rahatça iletme firsat verdiğini belirtmiştir. Oyun çocuğun bilişsel, sosyal, fiziksel ve duygusal gelişimini etkiler (Saracho ve Spodek, 1998). Pellegrini ve diğerleri (2007) oyunun anlamsız ve işlevsiz değil, aksine işe yarar, çok amaçlı ve işlevsel bir davranış olduğunu belirtmişlerdir; çünkü çocuk oyun oynarken çevresini örnek alır ve bu sayede çevresine uyumlu davranışları öğrenir ve sergiler. Nicolopoulou (2010) da bu yüzden, öğrenmeyi ve gelişimi destekleyecek şekilde okul öncesi öğretim programlarına oyunun entegre edilmesinin önemli olduğunu vurgulamıştı. Alan yazın incelendiğinde oyunun çeşitli tanımlarının yapılmış olduğu; fakat yapılan bu tanımların kapsayıcı olmadığı görülmüştür. Çelebi (2007)'ye göre, çok yönlü bir kavram olan oyunun tek bir tanımını yapmak mümkün değildir. Schwartzman (1978) bütün toplumlarda genç ve çocuk olan insan bireylerinin oyun oynadığını belirtmiştir. Çocukların oyunlarının türleri ve formları, oynadıkları oyunun süreleri, yaşa, cinsiyete, kültürel bağlama ve oyun ortamının çevresel özelliklerine bağlı olarak değişiklik gösterir (Sutton-Smith, 1997). Alan yazında birçok araştırmacı tarafindan oyunun çeşitli tanımları yapılmıştır. Zimmerman (2004) oyunu bir miktar katı yapı içerisinde esnek hareket biçimi olarak tanımlamıştı. Ona göre oyun hem bu katı yapı sayesinde hem de buna rağmen ortaya çıkmaktadır. Restal ve Magill-Evans (1994) oyunu çocukların beceri geliştirdiği, rollere büründüğü ve etkileşim içerisinde bulunduğu bir araç olduğunu belirtmişlerdir. Eyüboğlu (1995) ise, Türk Dilinin Etimolojik Sözlüğü’nde Türkçe "oy (çukur)" kökünden "oy-un (çukur açmak)" sözcüğünün türetildiğini sonradan sözcügün anlam genişlemesine uğrayarak "oynamak, biriyle eğlenmek, aldatmak" anlamlarında kullanılmaya başlandığını belirtilmiştir. Verenikina ve diğerleri (2003) oyunun yalnızca bir eğlence etkinliği ya da çocuğun kendiliğinden doğal olarak geliştirdiği davranışlar dizisi bütünü olmadığını, oyun tanımına davranışsal bakış açısıyla bakılırsa oyunun yeterince açık olmayan bir tanımının yapılmış olacağını belirtmişlerdir. Bilişsel gelişim kuramcıları oyunun yaratıcı ve problem çö- 
zücü zihinsel yönlerine vurgu yapmıştır (Vygotsky, 1967 aktaran Lindqvist, 2003). Sosyal ve hareketli, durağan olmayan bir olay olan oyunun çok boyutlu olması tam bir tanımını yapmayı zorlaştırmaktadır. Piaget (1962) oyunu, kendiliğinden ortaya çıkan, zevk için yapılan, bir düzenleme içermeyen eğlenceli bir davranış olarak ele alarak, oyunu bilişsel gelişimin bir parçası olarak tanımlamaktadır. Ayrıca Vygotsky (1978) de okul öncesi dönemde çocukların oyun etkinlikleriyle bilişsel fonksiyonları arasındaki ilişkiye vurgu yaparak oyuna ilişkin farklı bakış açısı kazanıımasını sağlamıştır. Böylece oyunun çocukların bilişsel gelişiminde oynadığı rol herkes tarafindan kabul edilen bir olgu haline gelmiştir. Oyunun tanımının yapılmasının yanı sıra karakteristik özelliklerinin belirlenmesi de önemlidir; çünkü oyunun karakteristik özellikleri yapacağımız oyunun tanımını doğrudan etkilemekte ve bazen değiştirmektedir. Oyunun karakteristik özellikleri; eğlenceli ve istenilir olması, hedeflerinin dıştan empoze edilmemiş olması, spontane ve gönüllü olması, bir miktar etkin katılım gerektirmesi, oyun ile oyun olmayan şeylerin sistematik bir yapı içerisinde karşılaştırılabiliyor olmasıdır (Garvey,1977). Etkinliğin sonunda çıkacak ürüne giden yollara dikkat edilmesi, esnek ve değişken özellikte olması, oyunda gerçekten ziyade mecazi bir yönelim olması oyunun diğer özelliklerindendir (Roeyers \& Van Berckelaer-Onnes, 1994). Garvey'e göre oyunun tam tarifini yapamasak bile en azından oyun olanla oyun-olmayanları fark edip karşılaştrabilmeliyiz. Rubin, Fein ve Vandenberg (1983) oyunu ve oyun davranışlarını inceleyerek oyunun karakteristik özelliklerini altı madde halinde tanımlamıştır:

(1) Oyun iştah açıcı güdülerle, sosyal taleplerle ya da davranışa dıştan yapılan müdahalelerle yönetilmez, motivesini içgüdüsel şeylerden alır.

(2) Oyun spontane oynanır, dış kısıtlamalardan bağımsızdır.

(3) Oyunda bu nesne ya da kişi nedir diye değil, bu nesne ve kişiyle ne yapabilirim diye sorulur.

(4) Oyun, yapmak istediği etkinliğin kendisini ciddi bir şekilde icra etmek değil, role bürünme, -mış gibi yapma olarak tanımlayabileceğimiz etkinlikler bütünüdür.

(5) Oyun dıştan empoze edilmiş kurallardan bağımsızdır, bu çocuk oyununu kurallı oyunlardan ayırır.

(6) Oyun aktif kathlım gerektirir, bu da oyunu hayale dalmak, uzanmak ve amaçsız kaytarmaktan ayıran özelliğidir.

Vygotsky'e göre (1978) oyun içerisinde sıkıştııımış formda bütün gelişim özelliklerini barındııı. Oyunu diğer oyun olmayanlardan ayıran özellikleri vardır: "Çocuğun oyun davranışını diğer etkinlik davranışlarından ayıran bir kriter de çocuğun oyun oynarken kendisine "yap-inan" durumları yaratmasıdır. Bu da okul öncesi dönemde, görsel alanla duyusal alanın birbirinden ayırt edildiğini gösterir" (Vygotksy'den aktaran Lindqvist, 2003). Vygotsky, oyun etkinliğinde çocuğun görsel alandan duyusal alana geçişini daha yüksek zihinsel gelişim evrenine atladığının belirtisi sayar ve sözlü düşünmeye doğru gidildiğini belirtir. Çocuk oyun oynarken karşısında gördüğü şey tektir ama ona tepkide bulunurken farklı davranışlar sergileyebilir; bu çocuğun etkinlik halinde iken gördüğü şeyden bağımsız hareket ettiğini göstermektedir. Çocuklar sadece oyun etkinliklerinin türlerini değil aynı zamanda bu etkinliklerde birlikte olacağı çocukları da seçer. Çocukların oyun davranışlarını sosyal açıdan inceleyen taksonomi Parten'e aittir. Parten (1932) çalışmasında çocukların sosyal katlımı ile ilgili 6 kategori kullanmış, bunlardan dördünü sosyal olmayan ya da yarı-sosyal etkinlikler ve ikisini de sosyal olarak etkileşimli oyun davranışları olarak tanımlamıștr. Ona göre oyun davranışları "meşguliyetsiz oyun, seyirci davranış, yalnız oyun, paralel oyun, birleştirici oyun ve işbirlikçi oyun" türlerine ayrılmaktadır. Piaget (1962) oyun davranışını belirli bir sırayı takip eden düzenli bölmelere ayırmıştır. Piaget oyunu işlevsel (duyu-motor), sembolik (role bürünerek) ve kurallı oyun olarak üçe ayırır. Oyun kendi içerisinde dikkat etme, bağlant kurma, duygusal olarak bir şeye yönelme, olayı hikayeleştirme yeteneğini barındırır. Nesnelerin keşfiyle, basit tekrar içeren oyunlarla, nesnelerle bağlant kurma ve nesnelerin fonksiyonel özelliklerinin farkında olup amaçlı problem çözme gibi etkinlerle oyun sayesinde bilişsel gelişim sağlanır. Smilansky (1968) oyun sınıflamasına dramatik ve yapı inşa oyununu dahil etmiştir. Onun oyun sınıflaması dört boyutludur. Bunlar: İşlevsel oyun, yapı-inşa oyunu, dramatik oyun, kurallı oyundur. Smith ve Pellegrini (2008) ise oyun davranışlarını "Lokomotor oyun - Sosyal oyun- -Öyleymiş gibi yapma oyunu- Nesnelerle oyun- Dil oyunu olarak sınıflandırmıştır. Coplan ve Rubin (1998) tarafindan geliştirilen ve Gülay-Ogelman (2012) tarafindan çocukların oyun sırasında gösterdikleri davranışlar "sessiz davranış, yalnız-pasif davranış, yalnız-aktif davranış, sosyal oyun ve itiş-kakış oyun" olmak üzere beş boyuttan oluşmaktadır

Bu çalışma kapsamında ele alınan araştırma problem ve altproblemi şu şekildedir:

1. Okul öncesi dönemi çocuklarının oyun davranış düzeyleri nasıldır?

1.1. Okul öncesi dönemi çocuklarının oyun davranışları çeşitli değişkenlere (öğrenim görülen kurum türü ve kardeş sayısı) göre farklılık göstermekte midir?

\section{Yöntem}

Okul öncesi dönemi çocuklarının sessiz oyun, yalnız-pasif oyun, yalnız-aktif oyun, sosyal oyun ve itiş-kakış oyun davranışlarını belirlemek ve çeşitli değişkenler bağlamında farklılaşıp farklılaşmadığını ortaya çıkarmak amacıyla gerçekleştirilen çalışmada betimsel araştırma yöntemi kullanılmıştır. 


\section{Çalışma Grubu}

Bu araştırmanın çalışma grubunu Mersin illinde seçkisiz olarak belirlenen özel ve devlet okul öncesi eğitim kurumlarında öğrenim gören 60-72 aylık 200 çocuk oluşturmaktadır. Araştırmacılar kurumlarda görev yapan öğretmenlerle görüşerek, öğretmenlerden oyun davranışı ölçeğini her çocuk için gözlemlerine dayanarak doldurmalarını istemiştir. Görüşme sürecinde öğretmenlere çalışmanın amacı açıklanarak, ölçek maddelerine ilişkin açıklamalar yapılmıştır. ÇaIışmaya katılan çocukların 117'si (\%58.5) kız; 83'ü (\%41.5) erkektir. Çocuklardan 120'si (\%60) özel kurumlarda öğrenim görürken; 80'i (\%40) devlet kurumlarında öğrenim görmektedir. Çocuklardan 80'i (\%40) kardeşi olmadığını, 102'si (\%51) bir kardeşe sahip olduğunu, 18'si (\%9) iki kardeşe sahip olduğunu belirtmiştir.

\section{Veri Toplama Aracı}

Coplan ve Rubin (1998) tarafindan geliştirilen ve Gülay-Ogelman (2012) tarafindan Türkçe'ye uyarlanan Okul Öncesi Oyun Davranışı Ölçeği, küçük çocukların oyun sırasında gösterdikleri davranışları öğretmen görüşleri doğrultusunda belirlemek amacıyla kullanımıştır. Ölçek, sessiz davranış, yalnız-pasif davranış, yalnız-aktif davranış, sosyal oyun ve itiş-kakış oyun olmak üzere beş alt ölçekten ve 18 maddeden oluşmaktadır. Sessiz oyun alt ölçeği, etrafi amaçsızca izlemeye dayalı maddelerden; yalnız-pasif oyun alt ölçeği, çocuğun yalnız başına oynadığı, bir şeyleri inşa etmeye, kurmaya ve keşfetmeye dayalı oyun davranışlarını gösteren maddelerden; yalnız-aktif oyun ölçeği, çocuğun tek başına oynadığı koşma, müzik aleti çalma ya da canlandırmalar, rol-oynamalar gibi oyunları içeren maddelerden; sosyal oyun alt ölçeği, grup oyunu, sosyo-dramatik oyun ve akran etkileşimine dayalı maddelerden; itiş-kakış oyun alt ölçeği, kavga ediyormuş gibi yapmak, boğuşmak gibi harekete dayalı maddelerden oluşmaktadır. Alt ölçeklere ilişkin Cronbach Alpha güvenirlik katsayıları sırasıyla $.82, .80, .81, .89$ ve .89 olarak hesaplanmıştır.

\section{Veri Analizi}

Çalışmada okul öncesi dönemi çocuklarının oyun davranışları betimsel istatistikler yardımıyla saptanmıştı. Verilerin dağılımın normalliği incelenmiş ve verilerin +1.5 ve -1.5 aralığında olduğu, dolayısıyla dağılımın normal olduğu varsayılmıştır (Tabachnick ve Fidell, 2013). Ayrıca istatistiksel testler yardımıyla dağılımın normalliği incelenmiştir.

\section{Tablo 1 Oyun Davranışlarına iliş̧in Normallik Testi}

\begin{tabular}{lccc}
\hline & \multicolumn{3}{c}{ Kolmogorov-Smirnov Testi } \\
\cline { 2 - 4 } & ístatistik & sd & Sig. \\
\hline Sosyaloyun &, 193 & 200 &, 062 \\
Yalnızaktifoyun &, 204 & 200 &, 078 \\
Sessizoyun &, 156 & 200 &, 056 \\
İtiskakısoyun &, 215 & 200 &, 070 \\
yalnızpasifoyun &, 154 & 200 &, 082 \\
Oyuntoplam &, 126 & 200 &, 066 \\
\hline
\end{tabular}

Yapılan Kolmogorov-Smirnov normallik testi sonucunda verilerin her bir altölçek için normal dağıldığı (p>.05) görülmüştür; dolayısıyla çocukların oyun davranışları ve bu davranışlarının öğrenim görülen kurum ile kardeş sayısı değişkenlerine göre farklılaşma durumu ortalamalar arası fark testlerinden t-testi ve ANOVA ile belirlenmiştir.

\section{Bulgular}

Okul öncesi dönemi çocuklarının oyun davranışlarına ilişkin aritmetik ortalama ve standart sapma değerleri Tablo 2'de sunulmuştur.

Tablo 2. Çocukların Oyun Davranışları Betimsel Analiz Sonuçları

\begin{tabular}{lccccc}
\hline Alt Ölçekler & N & Min. & Maks. & $\overline{\mathbf{X}}$ & SS \\
\hline Sosyal oyun & 200 & 17,00 & 30,00 & 22,43 & 2,55 \\
Yalnız-aktif oyun & 200 & 6,00 & 10,00 & 7,32 & 1,07 \\
\hline Sessiz oyun & 200 & 7,00 & 15,00 & 11,48 & 2,23 \\
İtiş-kakış oyun & 200 & 4,00 & 10,00 & 7,19 & 1,54 \\
Yalnız-pasif oyun & 200 & 10,00 & 18,00 & 13,91 & 1,41 \\
Toplam & 200 & 53,00 & 72,00 & 62,34 & 4,05 \\
\hline
\end{tabular}


Tablo 2 incelendiğinde, okul öncesi dönemi çocuklarının en çok sosyal oyun davranışı sergiledikleri, ondan sonra yalnız-pasif oyun ve sessiz oyun davranışları sergiledikleri görülmektedir. En az gösterilen oyun davranışları ise itiş-kakış oyun ve yalnız-aktif oyundur. Okul öncesi çocukların toplam puandan elde ettikleri aritmetik ortalama değerlere bakarak çocukların sık sık oyun davranışı sergiledikleri söylenebilir. Çocukların oyun davranışlarında öğrenim görülen kurum türüne göre anlamlı bir farklıık olup olmadığının belirlenmesinde gerçekleştirilen ilişkisiz örneklemler için t-testi sonuçları Tablo 3'de sunulmuştur.

Tablo 3. Çocukların Oyun Davranışları Betimsel Analiz Sonuçları

\begin{tabular}{|c|c|c|c|c|c|c|c|c|}
\hline & & & $\mathrm{N}$ & $\overline{\mathrm{X}}$ & SS & $\mathrm{sd}$ & $\mathrm{t}$ & $\mathrm{p}$ \\
\hline \multirow{12}{*}{ 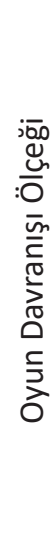 } & \multirow{2}{*}{ Sosyal oyun } & Devlet kurumu & 120 & 22,28 & 2,54 & \multirow{2}{*}{198} & \multirow{2}{*}{-.993} & \multirow{2}{*}{.322} \\
\hline & & Özel Kurum & 80 & 22,65 & 2,58 & & & \\
\hline & \multirow{2}{*}{ Yalnız-aktif oyun } & Devlet kurumu & 120 & 7,13 & 1,02 & \multirow{2}{*}{198} & \multirow{2}{*}{3.172} & \multirow{2}{*}{.002} \\
\hline & & Özel Kurum & 80 & 7,61 & 1,08 & & & \\
\hline & \multirow{2}{*}{ Sessiz oyun } & Devlet kurumu & 120 & 11,67 & 2,07 & \multirow{2}{*}{198} & \multirow{2}{*}{1.477} & \multirow{2}{*}{.141} \\
\hline & & Özel Kurum & 80 & 11,20 & 2,43 & & & \\
\hline & \multirow{2}{*}{ İtiş-kakış oyun } & Devlet kurumu & 120 & 7,08 & 1,47 & \multirow{2}{*}{198} & \multirow{2}{*}{1.197} & \multirow{2}{*}{.233} \\
\hline & & Özel Kurum & 80 & 7,35 & 1,64 & & & \\
\hline & \multirow{2}{*}{ Yalnız-pasif oyun } & Devlet kurumu & 120 & 13,86 & 1,41 & \multirow{2}{*}{198} & \multirow{2}{*}{-.591} & \multirow{2}{*}{.555} \\
\hline & & Özel Kurum & 80 & 13,98 & 1,41 & & & \\
\hline & \multirow{2}{*}{ Toplam } & Devlet kurumu & 120 & 62,04 & 4,26 & \multirow{2}{*}{198} & \multirow{2}{*}{1.297} & \multirow{2}{*}{.196} \\
\hline & & Özel Kurum & 80 & 62,80 & 3,70 & & & \\
\hline
\end{tabular}

Tablo 3 incelendiğinde, çocukların yalnız-aktif oyun davranışlarında öğrenim görülen kurum türüne göre anlamlı bir farklılık olduğu görülmektedir $\left(\mathrm{t}_{(198)}=3.172, \mathrm{p}<.05\right)$. Özel kurumda öğrenim gören okul öncesi dönemi çocuklarının yalnız-aktif oyun davranışlarının devlet kurumlarında öğrenim görenlere kıyasla daha yüksek olduğu görülmüştür. Çocukların oyun davranışlarında kardeş sayısına göre anlamlı bir farklılık olup olmadığının belirlenmesinde gerçekleştirilen tek yönlü varyans analizi sonuçları Tablo 4'te sunulmuştur.

Tablo 4. Çocukların Oyun Davranışları Betimsel Analiz Sonuçları

\begin{tabular}{|c|c|c|c|c|c|c|}
\hline & Varyansın Kaynağı & Kareler Toplamı & $\mathrm{Sd}$ & Kareler Ortalaması & $\mathrm{F}$ & $p$ \\
\hline \multirow{3}{*}{ Sosyal oyun } & Gruplararası & 22,053 & 2 & 11.027 & \multirow{3}{*}{1,696} & \multirow{3}{*}{186} \\
\hline & Gruplariçi & 1280,967 & 197 & & & \\
\hline & Toplam & 1303,020 & 199 & 6,502 & & \\
\hline \multirow{3}{*}{ Yalnız-aktif oyun } & Gruplararası & 3,801 & 2 & 1,900 & \multirow{3}{*}{1,671} & \multirow{3}{*}{ 191 } \\
\hline & Gruplariçi & 224,074 & 197 & & & \\
\hline & Toplam & 227,875 & 199 & 1,137 & & \\
\hline \multirow{3}{*}{ Sessiz oyun } & Gruplararası & 5,116 & 2 & 2,558 & \multirow{3}{*}{,510 } & \multirow{3}{*}{,602 } \\
\hline & Gruplariçi & 988,839 & 197 & & & \\
\hline & Toplam & 993,955 & 199 & 5,019 & & \\
\hline \multirow{3}{*}{ İtiş-kakış oyun } & Gruplararası & 14,614 & 2 & 7,307 & \multirow{3}{*}{3,128} & \multirow{3}{*}{,046 } \\
\hline & Gruplariçi & 460,166 & 197 & & & \\
\hline & Toplam & 474,780 & 199 & 2,336 & & \\
\hline \multirow{3}{*}{ Yalnız-pasif oyun } & Gruplararası & 6,613 & 2 & 3,306 & \multirow{3}{*}{1,666} & \multirow{3}{*}{ 192 } \\
\hline & Gruplariçi & 390,942 & 197 & & & \\
\hline & Toplam & 397,555 & 199 & 1,984 & & \\
\hline \multirow{3}{*}{ Toplam } & Gruplararası & 38,714 & 2 & 19,357 & \multirow{3}{*}{1,178} & \multirow{3}{*}{,310 } \\
\hline & Gruplariçi & 3238,481 & 197 & & & \\
\hline & Toplam & 3277,195 & 199 & 16,439 & & \\
\hline
\end{tabular}

Tablo 4 incelendiğinde, çocukların itiş-kakış oyun davranışlarında kardeş sayısı değişkenine göre anlamlı bir farklıık olduğu saptanmıştır $F(2,197)=3.128 ; p<.05$. Gözlenen farklılığın hangi gruplar arasındaki farklılıktan kaynaklandığının belirlenmesinde gerçekleştirilen LSD testi sonuçları kardeşi olmayanların $(\bar{x}=7.00)$ bir $(\bar{x}=7.31)$ ya da iki kardeşi $(\bar{x}=8.75)$ olanlara kıyasla daha düşük itiş-kakış oyun oynadıklarını göstermektedir. Bu bağlamda kardeş sayısının çocukların oyun davranışlarını özellikle itiş-kakış oyun davranışlarını etkilediği ileri sürülebilir. 


\section{Sonuçlar}

Bu çalışmanın bulguları incelendiğinde, okul öncesi dönemi çocuklarının oyun davranışları olarak sosyal oyun, yalnız-aktif oyun, sessiz oyun, itiş-kakış oyun, yalnız-pasif oyun alt ölçeklerinden yüksek puanlar aldığı; sosyal yeterlik ve okula uyum ölçeğinden ise akran tercihli sosyal davranış, öğretmen tercihli sosyal davranış ile okula uyum alt ölçeklerinden yüksek puanlar aldıkları görülmüştür. Bu durumda, çocukların sık sık çeşitli kategorilerde oyun davranışları gösterdikleri, sosyal yeterlik ve okula uyum davranışı açısından ise yüksek düzeyde davranışlar sergiledikleri söylenebilir. Çocukların oyun davranışlarının kardeş değişkenine göre farklılaşıp farklılaşmadığına bakıldığında, kardeşi olmayan çocukların bir ya da iki kardeşi olanlara kıyasla daha düşük itiş-kakış oyun oynadıkları görülmüştür. Taylı (2007) araştırmasında tek çocukların kardeşli çocuklara göre daha çok yalnız oyun oynadıkları bulgusuna ulaşmıştır; ona göre yalnız oyun en çok görüş ayrılıklarının olduğu oyundur. Ayrıca, pasif yalnız oyunun, arkadaşları tarafindan dışlanma, kişilerarası ilişki güçlükleri ve problemin içselleştirilmesiyle ilişkili olduğu; aktif yalnız oynamanın ise daha az durağan olduğu, saldırganlık ve problemin dışsallaştırıması ile ilişkili olduğu bulunmuştur. Kardeşli çocuklar birlikte ve işbirlikçi oyun etkinliği \%73 oranında tercih ederken, tek çocuklar \%55 oranında tercih etmişlerdir. Ogleman ve Sarıkaya (2014)'nın yaptığı çalışmada ise yalnız-pasif ve yalnız-aktif davranış düzeyi arttkç̧a çocukların olumlu sosyal davranışlarının arttı̆ı; fakat, itiş-kakış oyun düzeyi arttıkça aşırı hareketlilik, saldırganlık, korkulu-kaygılı olma ve akran şiddetine maruz kalma düzeyinin arttğı bulgusuna ulaşılmıştır.

Bu çalışma kapsamında, çocukların oyun davranışlarının eğitim aldıkları kurum türüne göre farklılaşıp farklılaşmadığına bakıldığında ise özel kurumda öğrenim gören okul öncesi dönemi çocuklarının yalnız-aktif oyun davranışlarının devlet kurumlarında öğrenim görenlere kıyasla daha yüksek olduğu görülmüştür. Yalnız-aktif davranış, çocuğun yalnız başına nesnelerle ya da nesneler olmaksızın kendi becerileri ile gerçekleştirdiği canlandırmalar ve rol oynamalardır (Coplan ve diğerleri, 1998). Okul öncesi kurumun türüyle ilgili olarak Altay ve Güre (2012) tarafindan yapılan çalışmada, sosyal yeterliğin alt boyutlarından akranlarla olan negatif ilişkiler ve katılım açısından farklılaştığını göstermiştir. Özel okul öncesi eğitim kurumuna devam eden çocukların, devlete bağlı olan okul eğitim kurumuna devam edenlere göre akranlarına karşı daha fazla saldırgan davranış gösterdikleri ve katılımcı olmayan davranışlar sergiledikleri bulgusuna ulaşılmıştı. Ogleman ve Sarıkaya (2014)'nın yaptı̆ı̆ çalışmada ise çocukların sessiz oyun düzeyi arttkça, korkulu kaygıı olma ve sosyal olmayan davranış düzeyinin de arttğı; olumlu sosyal davranış düzeyinin ise azaldığı ortaya çıkmıştı. Sosyal oyun düzeyi arttıkça olumlu sosyal davranış düzeyi artmakta, sosyal olmayan davranış düzeyi azalmaktadır.

Çocukların saldırganlık davranışlarını oyun yoluyla inceledikleri çalışmada, Ostrov ve Keating (2004) okul öncesi erkek çocukların oyun davranışlarında göstermiş olduğu fiziksel saldırganlık daha çok olduğu, erkek çocuklar fiziksel saldırganlığı seçerken, kız çocuklar ise ilişkisel saldırganlığı seçtiği sonucuna ulaşmışlardır. Altay ve Güre (2012) sosyal yeterlik açısından cinsiyet farklılıklarını incelemiş ve kızların akranlarıyla işbirliği yapma, onlarla eşyalarını paylaşma, zor durumda onları teselli etme gibi davranışları erkeklere göre daha sık ortaya koyduklarını; erkek çocukların ise kızlara göre akranlarına karşı daha fazla fiziksel ve sözel saldırganlık gösterdiklerini belirtmiştir. Connoly ve Doyle (1984), çocuk oyunlarından dramatik oyunun ve dramatik olmayan oyunların, çocukların toplum kurallarını anlamasına, uyum göstermesine ve toplumsallaşmasına etkisini incelemiş ve dramatik oyunun diğerlerine göre çocuğun toplum kurallarını öğrenmesine ve gündelik yaşantısına geçirmesine daha etkili olduğu bulgusuna ulaşmışlardır. Çalışmada arkadaşları ile etkileşim içinde olan çocukların toplum rollerini ve kuralları daha iyi öğrendiği ve sosyal oyunun çocuğun olumlu sosyal gelişimi açısından önemli olduğu ortaya çıkmıştır.

\section{5. Öneriler}

İlköğretim dönemine geçiş öncesi en kritik deneyimlerin edinildiği okul öncesi dönemde yaşanılacak bir okul uyumsuzluğu probleminin çocukların sosyal-duygusal gelişimi, ders başarısı, akademik yaşama karşı tutumu açısından olumsuz sonuçlar doğuracağı öngörülmektedir. Okul öncesi dönemde çocuğun oyun davranışları incelenerek ileride ortaya çıkabilecek zorbalık davranışları belirlenip bu durumu ortadan kaldırmaya yönelik etkinlikler düzenlenebilir. Ayrıca, okulöncesi çocukların oyun davranışlarının okula uyumu kolaylaştıracağı ya da zorlaştıracağı düşünülmektedir. Bu durumun ilerleyen zamanlarda akran ilişkilerini de olumlu ya da olumsuz etkileyeceği düşünülmektedir. Çocukların oyun davranışları belirlenerek içerisinde bulundukları bilişsel ve duyuşsal duygu durumuna göre çeşitli oyun davranışlarının edinmesine yönelik etkinlikler yaptırılabilir, ayrıca oyun davranışları ile okula uyum ve sosyal yeterlik değişkenlerine yönelik çalışmalar yapılabilir. Bu çalışma çocukların oyun davranışları hakkında önemli bulgular ortaya koymuştur. Bu çalışmanın bulgularının genellenebilmesi, farklı ortamlarda benzer sonuçlara ulaşılıp ulaşılamayacağının belirlenmesi amacıyla diğer araştırmacılara farklı kültürel ve sosyal bağlamlarda çalışma yapmaları önerilmektedir. 


\section{Kaynakça}

Altay, F. B., \& Güre, A. (2012). Okul öncesi kuruma (devlet-özel) devam eden çocukların sosyal yeterlik ve olumlu sosyal davranışları ile annelerinin ebeveynlik stilleri arasındaki ilişkiler. Kuram ve Uygulamada Eğitim Bilimleri, 12(4), 2699-2718.

Aslan, Ö. M. (2013). Anaokuluna Devam Eden Çocukların Oyun Davranışları ve Oyunlarında Ortaya Çıkan Zorbalık Davranışları. Yayımlanmamış Doktora Tezi, Hacettepe Sosyal Bilimler Enstitüsü, Ankara

Bierman, K. L., \& Motamedi, M. (2015). Social and emotional learning programs for preschool children. In Durlak, Domitrovich, Weissberg ve Gullota, Handbook, 135-50.

Cohen, J. S., \& Mendez, J. L. (2009). Emotion regulation, language ability, and the stability of preschool children's peer play behavior. Early Education and Development, 20(6), 1016-1037.

Connolly, J. A., \& Doyle, A. B. (1984). Relation of social fantasy play to social competence in preschoolers. Developmental Psychology, 20 (5), 797.

Coplan, R. J., \& Rubin, K. H. (1998). Exploring and assessing nonsocial play in the preschool: The development and validation of the Preschool Play Behavior Scale. Social Development, 7(1), 72-91.

Çelebi, D. B. (2007). Türkiye ve Azerbaycan'daki çocuk oyunları ve oyuncaklarının karşılaştırmalı olarak incelenmesi. Yayınlanmamış Yüksek Lisans Tezi. Muğla Üniversitesi Sosyal Bilimler Enstitüsü, Muğla

Eyüboğlu, Z. İ., (1995), Türk Dilinin Etimoloji Sözlüğü, Sosyal Yayınları, İstanbul, s. 520 “oyun” maddesi

Garvey, C. (1977) Play. London: Fontana.

Ginott, H. G. (1994). Group psychotherapy with children: The theory and practice of play-therapy. Rowman \& Littlefield.

Gülay-Ogelman, H. (2012). Okul öncesi oyun davranış ölçeğini Türkçe'ye uyarlama çalışması. Uluslararası Hakemli Akademik Sosyal Bilimler Dergisi, 3(2), 201-221.

Günalp, A. (2007). Farklı anne baba tutumlarının okul öncesi eğitim çağındaki çocukların özgüven duygusunun gelişimine etkisi (Aksaray ili Örneği). Yüksek Lisans Tezi, Selçuk Üniversitesi Sosyal Bilimler Enstitüsü, Ankara

Kaytez, N. ve Durualp, E. (2014). Türkiye'de okul öncesinde oyun ile ilgili yapılan lisansüstü tezlerin incelenmesi. Uluslararası Türk Eğitim Bilimleri Dergisi, 2014(2). 110-123

Lindqvist,G. (2003): Vygotsky's Theory of Creativity. Creativity Research Journal. 15(2-3) : $245-251$

Nicolopoulou, A. (2010). The Alarming Disappearance of Play from Early Childhood Education. Human Development. 53,(1-4)

Ogelman, H. G., \& Sarıkaya, H. E. (2014). Okul öncesi dönem çocuklarının oyun davranışlarının akran ilişkileri üzerindeki yordayıcı etkisi. Abant İzet Baysal Üniversitesi Sosyal Bilimler Enstitüsü Dergisi, 14(3).

Ostrov, J. M. ve Keating, C. F. (2004), Gender Differences in Preschool Aggression During Free Play and Structured Interactions: An Observational Study. Social Development. 13, 255-277

Parten, M. B. (1932). Social participation among preschool children. Journal of Abnormal and Social Psychology. 27, $243-269$.

Pellegrini, A. D., Dupuis D., ve Smith P.K. (2007) Play in evolution and development. Developmental Review. 27, $261-276$

Piaget, J.(1962). Play, dreams and imitation in children, New York: Norton.

Restal, G. ve Magill-Evans, J. (1994). Play and preschool children with autism. American Journal of Occupational Theraphy, 48(2), 113-120

Roeyers, H., ve Van Berckelaer-Onnes, I. A. (1994) - Play in autistic children. Communication and Cognition. 27 (3), 349-360

Rubin, K.H. , Fein, G.G. ve Vandenberg, B. (1983) 'Play'. Hetherington, E .M. (ed.) Handbook of Child Psychology: Socialization, Personality and Social Development. New York:Wiley.

Saracho, O. N. ve Spodek, B. (1998) Historical Overview of Theories of Play. Multiple perspectives on play in early childhood (1-9). Albany: State University of New York Press.

Schwartzman, H.B. (1978). Transformations: the anthropology of children's play. New York: Plenum Press.

Smilansky, S. (1968). The effects of socio-dramatic play on disadvantaged preschool children. [Aktaran: Rubin, K.H. (2001) The Play Observation Scale (POS). Center for Children, Relationships, and Culture. University of Maryland]

Smith, K.P. ve Pellegrini, A. (2008) Learning Through Play. Encyclopedia on Early Child Education. Goldsmiths, University of London, UK

Strayer, D. L., Downing, J. A., Haag, W. R., King, T. L., Layzer, J. B., Newton, T. J., \& Nichols, S. J. (2004). Changing perspectives on pearly mussels, North America's most imperiled animals. BioScience, 54(5), 429-439.

Sutton-Smith, B. (1997), The ambiguity of play. Cambridge, Mass.: Harvard University Press.

Taylı, A. (2007). Kardeş sahibi olup olmama durumunun okulöncesi dönemdeki sosyal oyuna etkisi. Abant İzzet Baysal Üniversitesi Eğitim Fakültesi Dergisi. 7(1), 103-115

Vandenberg B., ve Kielhofner G. (1982) Play in evolution, culture and adaptation. The American Journal of Occupational Therapy. 36(1), 20-28

Verenikina, I., Harris, P. ve Lysaght, P. (2003). Child's play: Computer games, theories of play and children's development. Proceedings of the international federation for information processing working group 3.5 open conference on Young children and learning technologies, 99-106, Sidney,Avustralya

Vygotsky, L. S. (1966). Play and its role in the mental development of the child. Voprosy Psikhologii, 12, 62-67

Vygotsky, L. S. (1978) Mind in Society: The Development of Higher Psychological Processes. Cambridge, MA: Harvard University Press.

Youngblade, L. M., \& Dunn, J. (1995). Individual differences in young children's pretend play with mother and sibling: Links to relationships and understanding of other people's feelings and beliefs. Child Development, 66(5), 1472-1492.

Zimmerman, E. (2003). Play as research: The iterative design process. Design research: Methods and perspectives, 2003, $176-184$. 